\title{
Responses of Dendrobium 'darrenn glory' and Mokara 'calypso jumbo' orchids to 1-methylcyclopropene and aqueous ozone postharvest treatments
}

\author{
Parviz Almasi ( $\left.{ }^{1}\right)$; Mahmud Tengku Muda Mohamed (2); Parvez Anwar (3,4*); Siti Hajar Ahmad ( ${ }^{5}$ ); \\ Jugah Kadir $\left({ }^{6}\right)$ \\ (') University of Sayyed Jamaleddin Asadabadi, Asadabad, 6541835583, Iran. \\ (2) Universiti Putra Malaysia, Institute of Tropical Agriculture, Department of Crop Science, 43400 UPM Serdang, Selangor, Malaysia. \\ (3) Universiti Putra Malaysia, Institute of Tropical Agriculture, 43400 UPM Serdang, Selangor, Malaysia. \\ (4) Bangladesh Agricultural University, Department of Agronomy, Mymensingh-2202, Bangladesh. \\ (5) Universiti Putra Malaysia, Department of Crop Science, 43400 UPM Serdang, Selangor, Malaysia. \\ ${ }^{\left({ }^{6}\right)}$ Universiti Putra Malaysia, Department of Plant Protection, 43400 UPM Serdang, Selangor, Malaysia. \\ (*) Corresponding author: parvezagron@yahoo.com
}

Received: Mar. 23, 2015; Accepted: May 25, 2015

\begin{abstract}
Orchids possess a very special place amongst ornamental plants. But high ethylene sensitivity and early flower senescence of orchid result in a short vase life and rapid quality deterioration which is of great concern for the growers, traders and

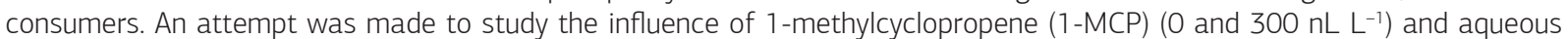
ozone $\left(0\right.$ and $\left.5.2 \mathrm{~nL} \mathrm{~L}^{-1}\right)$ in prolonging vase life and maintaining quality of two cut orchid hybrids Dendrobium 'Darren Glory' (DDG) and Mokara "Calypso Jumbo" (MCJ). Results showed that orchid hybrids exhibited differences in their ethylene sensitivity, vase life, 1-aminocyclopropane-1-carboxylic acid (ACC) content and ACC oxidase activities. Pre-treatment with 1-MCP resulted in reduced ethylene production, vase life, ACC content and ACC oxidase activities, but increased bud opening \%. Pre-treatment with aqueous ozone failed to influence all those parameters except bud opening \%. Interaction effects of hybrid and 1-MCP were significant for ethylene production, hybrid and ozone for vas life, 1-MCP and ozone for bud opening \%, and hybrid, 1-MCP and ozone for ethylene production and vase life. Aqueous ozone markedly contributed to the inhibition of microbial growth in vase solution. Pre-treatment of the cut orchid flowers with $300 \mathrm{~nL} \mathrm{~L} \mathrm{~L}^{-1} 1-\mathrm{MCP}$, followed by using $5.2 \mathrm{mg} \mathrm{L}^{-1}$ aqueous ozone as the vase solution could be recommended to maintain quality and extend vase life of both the DDG and MC) orchid hybrids.
\end{abstract}

Key words: ethylene sensitivity, vase life, 1-methylcyclopropene, aqueous ozone, orchid quality.

\section{INTRODUCTION}

Orchids are the most beautiful flowers and compose a unique group of plants. In terms of taxonomy, orchids belong to a highly evolved family Orchidaceae, which contains 600-800 genera and 25,000-35,000 species. Orchids display an extraordinary range of diversity in size, shape and color of flowers (Singh, 2006). In recent years, orchid industry has grown very rapidly, and thousands of orchid species have been introduced into cultivation (Chen et al., 1999). Malaysia, Thailand, Singapore, and the Philippines are the major cut-orchids exporters in Asia (Hew \& Yong, 2004). The second large genus in the family Orchidaceae is Dendrobium (Adams, 2011) that contains over 1000 species which have been distributed in the foothills of the Himalayas, through Southeast Asia to Japan, Australia, Tasmania and Pacific Islands. Dendrobium is a member of subfamily Epidendroideae, tribe Dendrobieae and subtribe Dendrobiinae (Dressler, 1990), and produces the most popular orchids. Mokara is a trigeneric (Arachnis $\times$ Ascocentrum $\times$ Vanada), monopodial and no pseudobulbs hybrid from Dendrobium Group (Epidendrum subfamily) which was developed in Singapore in 1969. The brilliant colors of Mokara have offered them top position among the other genera. Mokaras are often looking like Ascocenda hybrids, and their flowers can last 4-6 weeks. Mokara is the generic name which honors the hybridizer, C. Y. Moke (White, 1996). 
Orchid inflorescences display an extensive range of sensitivity to ethylene (Goh et al., 1985; Uthaichay et al., 2007), which is often manifested as a progressive drying and bleaching of the sepals starting at the tips and extending towards the bases. Normally, floral buds are highly ethylene sensitive. Most of the ethylene emerged from floral buds rather than from open florets (Uthaichay et al., 2007). Abscission of Dendrobium floral buds and flowers occurs inside the closed cardboard boxes during transit. During transportation, flowers produce ethylene that accumulates inside the box causing the abscission of buds and flowers. Silver thiosulfate (STS) is an efficient and commonly used inhibitor against ethylene action, but it is not environment-friendly since contains heavy metal residue like silver (Van Doorn, 1998). The 1-methylcyclopropene (1-MCP) also is an efficient inhibitor against endogenous and exogenous ethylene action, and therefore it could be considered as a good alternative for STS because it does not have harmful heavy metal residue. Application of 1-MCP has been successful in extending vase life of different flowers like cut mini Phalaenopsis (Sun et al., 2009), Cattleya (Singh \& Jaroenkit, 2011; Yamane et al., 2004), Dendrobium (Uthaichay et al., 2007), carnation, delphinium and sweet pea (Ichimura et al., 2002).

One of the major causes for vase life reduction of many cut flowers is the presence of micro-organisms like bacteria, fungi or yeast in the holding solutions. Those microbes cause blockage in xylem conduits during vase life of cut flowers and limit water uptake. These blockages might due to microbial growth, production of tyloses, sediment of materials in the lumen of xylem vessels and the formation of air emboli in the vascular system (Twumasi et al., 2005). These disrupt water uptake and reduce the vase-life of cut flowers (Robinson et al., 2009). A high number of bacteria in the vase solution are mostly responsible for the vascular blockage (Kazemi \& Ameri, 2012; Robinson et al., 2009). To inhibit microbial growth in the vase solutions, many chemicals have been tried such as silver nitrate (Torre \& Fjeld, 2001), silver thiosulphate (Van Doorn, 1998), hydroxyquinoline citrate (Van Doorn, 1998), sodium hypoclorite (Torre \& Fjeld, 2001) and aqueous ozone (Robinson et al., 2009).

Ozone is a strong oxidizing agent with the ability to decrease numbers of bacteria and fungi for extensive range of uses (Kim et al., 1999). The effectiveness of aqueous and gaseous ozone on killing of microbes is well known, and it can be considered as a potential alternative method for the control of microbial growth in the vase solution of cut flowers. Robinson et al. (2009) reported that storing cut 'Pascha' roses in aqueous ozone at a concentration of $5.5 \mathrm{mg} \mathrm{L}^{-1}$ with daily renewal extended their vase-life almost three times. Ozone in water decomposes and produces diatomic oxygen and a number of free radicals such as superoxide, hydroperoxyl, and hydroxyl radicals (Staehelin et al., 1984) which attack organic and inorganic compounds in the solution. While others argued that the mechanism of action on bacterial lysis is through ozone-induced membrane oxidation (Komanapalli et al., 1997; Komanapalli \& Lau, 1998). They noted that more extensive oxidation was observed on membrane lipids compared to membrane proteins. Ozone also reacts with cell dehydrogenases and thus interferes with respiration and fermentation process in cells (Oyedotun \& Lemire, 2004). There is also an interference effect of ozone on cellular respiration. However, the required concentration of aqueous ozone for cell decomposition depends on conditions such as $\mathrm{pH}$, existence of contaminants, media, micro-organisms (bacteria, fungi, viruses) and biological stage of life (Kim et al., 2003).

Orchid hybrids DDG and MCJ have short vase life and high occurrence of florets epinasty which might be due to ethylene sensitivity and xylem blockage, but this issue has not been properly addressed so far. Present study was conducted to evaluate the effect of 1-MCP and aqueous ozone on quality and vase life of orchid hybrids Dendrobium 'Darrenn Glory' and Mokara 'Calypso Jumbo'.

\section{MATERIAL AND METHODS}

\section{Experimental site}

As per Köppen classification system, the experimental site ( $3^{\circ} 00^{\prime} 21.34$ ” N, 10142' 15.06” E, 37 m elevation) belongs to Tropical rainforest climate $(A f)$ which is characterized by constant high temperature $\left(18{ }^{\circ} \mathrm{C}\right.$ or higher) throughout the year, average precipitation of at least $60 \mathrm{~mm}$ in every month and no natural seasons. During the experimental period, monthly average maximum and minimum temperature and relative humidity ranged from 32.9 to $34.8{ }^{\circ} \mathrm{C}, 22.6$ to $24.4{ }^{\circ} \mathrm{C}$ and 93.7 to $95.9 \%$, respectively, while rainfall, evaporation and sunshine hours ranged from 4.8 to $13.4 \mathrm{~mm} /$ day, 3.9 to $4.4 \mathrm{~mm} \mathrm{day}^{-1}$ and 6.75 to $7.89 \mathrm{hrs} /$ day, respectively.

\section{Plant materials}

Two orchid hybrids namely Dendrobium 'Darren Glory' (DDG) and Mokara 'Calypso Jumbo' (MCJ) were used as the plant materials in this study. Orchids were purchased from a commercial farm. Inflorescences with 60 to 70 percent open florets were harvested between 8 to 9 a.m. and then immediately transported to the laboratory within one hour.

\section{Experimental design and treatments}

The experiment was conducted using a completely randomized design (CRD) in a factorial arrangement with five replications. Treatments comprised two orchid hybrids namely, DDG and MCJ, two different concentrations of 
1 - methyl cyclopropene (1-MCP) such as 0 (control) and $300 \mathrm{~nL} \mathrm{~L}^{-1}$, and two aqueous ozone concentrations such as 0 (control) and $5.2 \mathrm{mg} \mathrm{L}^{-1}$.

\section{MCP and aqueous ozone treatment}

Inflorescences of DDG and MCJ were subjected to 1 -MCP treatment within 1 hour of harvesting. In the laboratory, inflorescences were divided into two groups and placed in two Plexiglass chambers of size $51 \times 46.5 \times 33.5 \mathrm{~cm}^{3}$ each. To deliver $300 \mathrm{~nL} \mathrm{~L}^{-1} 1$-MCP, a small vial containing $37.92 \mathrm{mg}$ Ethyl bloc was taped to the respective chamber's internal wall. Then, $190 \mu \mathrm{L} \mathrm{L}^{-1}$ deionized water was added to the tube and the chambers were immediately sealed for 4 hours. To homogenize the air, small fans were placed inside the chamber. The chambers were opened for 1 hour airing. Then inflorescences of each chamber were divided to two subgroups and after labeling the 4 chambers they were placed inside them gently. The chambers were hermetically-sealed. Then, two separate $1 \mu \mathrm{L} \mathrm{L}^{-1}$ ethylene gas, balanced with nitrogen, were injected into the two chambers. After 24 hours, the chambers were opened and the inflorescences were taken out from them. Each inflorescence's basal stem was trimmed to $12 \mathrm{~cm}$ from the first open floret before being put into a cylindrical polyethylene (PE) bag (thickness $10 \mu \mathrm{m}$ ) containing $60 \mathrm{ml}$ distilled water. Each plastic bag was then held in a $300 \mathrm{~mL}$ glass bottle with cotton wool placed around each stem for the purpose of holding it upright. The inflorescences were kept in the laboratory at mean temperature, relative humidity and light intensity of $25{ }^{\circ} \mathrm{C}, 78 \%$ and $6.57 \mu \mathrm{mol} / \mathrm{m}^{2} / \mathrm{s}$, respectively. After four hours, the chambers were aerated and the stems were trimmed to $12 \mathrm{~cm}$ from the basal end of the first open floret. Each inflorescence was put into a bottle containing $250 \mathrm{~mL}$ of distilled water (control treatment) or $5.2 \mathrm{mg} \mathrm{L}^{-1}$ aqueous ozone (as prepared earlier). Cotton wool was placed around the stem for the purpose of positioning the stem upright. The inflorescences were placed in the laboratory under $25 \pm 2{ }^{\circ} \mathrm{C}, 78 \% \pm 2$ humidity and $6.57 \mu \mathrm{mol} / \mathrm{m}^{2} / \mathrm{s}$ light intensity, respectively. Every 24 hours, the ozonized water was renewed, but for the control, vase water was not changed until end of vase life.

\section{Measurement of ethylene production}

Two inflorescences of each treatment were incubated inside a $5.2 \mathrm{~L}$ container for 4 hours and $1 \mathrm{ml}$ sample from the headspace was taken using a syringe and injected into a gas chromatograph (Clarus 500 Gas Chromatograph Perkin Elmer, USA) fitted with a flame ionization detector and $30 \mathrm{~m}$ capillary column. The temperature of column was $70{ }^{\circ} \mathrm{C}$ while the temperature of injector and detector were
$200{ }^{\circ} \mathrm{C}$. The mean of ethylene production was calculated as $\mathrm{nL} / \mathrm{kg} \mathrm{h}^{-1}$.

\section{Measurement of bud opening}

Percentage of bud opening was calculated using following formula:

$$
\text { Bud Opening }(\mathrm{BO}) \%=\frac{B 1-B 2}{B 1} X 100
$$

$\mathrm{B} 1=$ initial number of buds and $\mathrm{B} 2=$ number of buds on the day of measurement

\section{Vase life determination}

Color, appearance and number of florets and buds were recorded for all flowers. Vase life was considered ended when more than one third of florets and buds wilted.

\section{1 -aminocyclopropane-1-carboxylic acid (ACC) content determination}

The method described by Podd et al. (2002), with some modifications, was used for ACC extraction. The third opened floret from the basal stem of each inflorescence in all treatment combinations was used for ACC extraction. The whole floret stored in $-70^{\circ} \mathrm{C}$ was placed in a mortar and pestle containing liquid nitrogen and ground precisely. Five hundred $\mathrm{mg}$ of the powdered plant material was incubated on ice for $2 \mathrm{~h}$ in $1 \mathrm{ml} 0.2 \mathrm{mM}$ sodium phosphate $\left(\mathrm{Na}_{3} \mathrm{PO}_{4}\right)$ buffer $(\mathrm{pH}=8.0)$. The mixture was centrifuged at $15,000 \mathrm{~g}$ for $30 \mathrm{~min}$ at $4{ }^{\circ} \mathrm{C}$ in a refrigerated centrifuge (Avanti J-25, Beckman Coulter, USA). The clear supernatant was used to determine the ACC content. The ACC assessment was done following Lizada \& Yang (1979). In this method, amount of ACC was determined with conversion of extracted ACC to ethylene. Ethylene production was measured by the gas chromatograph as described in 2.5. Assays were carried out in $12 \times 75 \mathrm{~mm}$ test tubes $(5 \mathrm{~mL})$. About $500 \mu \mathrm{L}$ plant extract and $1 \mu \mathrm{M} \mathrm{HgCl}_{2}$ were poured into each test tube. The mixture was brought to a volume of $900 \mu \mathrm{l}$ with distilled water. The reaction tubes were capped with rubber stoppers and held on ice. Using a $1 \mathrm{~mL}$ syringe, $100 \mu \mathrm{L}$ of a cold mixture of $5 \% \mathrm{NaOCl}$ and saturated $\mathrm{NaOH}(2: 1, \mathrm{v} / \mathrm{v})$ was injected through the rubber stopper into the tubes. The tubes were then vortexed for 5 second, kept on ice for 2.5 minutes, and then vortexed again (Lizada \& Yang, 1979). One mL of accumulated gases in the atmosphere of the sealed tube was taken using a syringe through the stopper, and injected into the injector port of the gas chromatograph to measure ethylene production. Results were expressed as $\mathrm{nmol} / \mathrm{g}$. 


\section{Measurement of ACC oxidase activity}

The activity of ACC oxidase was determined according to Podd et al. (2002), a method based on the original Lizada \& Yang (1979) protocol. After determination of ACC content in the florets on different days, ACC oxidase activity was calculated using five internal standards $(10,20$, 30,40 and $50 \mu \mathrm{M}$ ACC) combined with the internal ACC level. The enzyme activity was calculated by the conversion of ACC to ethylene. Data were expressed as a percentage of the maximum potential enzyme activity.

\section{Scanning electron microscopy}

Samples for scanning microscopy were prepared according to methods described by Jędrzejuk \& Sakrzewski (2009) with slight modifications. The samples (longitudinal and cross section of the stem base of orchid cut flower, about $1 \mathrm{~cm}^{3}$ were fixed in $4 \%$ glutaraldehyde over night at $4{ }^{\circ} \mathrm{C}$, washed twice, each time for 10 minutes in $0.1 \mathrm{M}$ sodium cacodylate buffer $(\mathrm{pH}$ 7.2-7.4) and post fixed in 1\% osmium tetroxide (wt/vol) for 20 hours at room temperature. After washing twice in the same buffer, the samples were dehydrated in a graded series of ethanol $(30 \%, 40 \%, 50 \%$, $70 \%, 75 \%, 80 \%, 90 \%$ and $100 \%$ ) for 30 minutes in each wash while the samples were washed three times in $100 \%$ ethanol for one hour each to discourage samples shriveling prior to critical point drying with carbon dioxide as the transition medium. The dried samples were then mounted on aluminium stubs using double-sided carbon tape and coated with gold in a sputter coater (Hammer V Sputter
Coater, Technic Alexanderia, USA). The samples were viewed and photographed with electron microscope (JEOL, JSM-5610LV, Tokyo, Japan).

\section{Statistical analysis}

The data were subjected to analysis of variance (ANOVA) by using SAS software version 9.1. Treatment means were compared by Duncan's Multiple Range Test (DMRT) at $\mathrm{p} \leq 0.05$.

\section{RESULTS AND DISCUSSION}

\section{Ethylene production}

Ethylene production by cut orchid was significantly influenced by orchid hybrid $(\mathrm{H})$ and 1-MCP concentrations (M) but not by aqueous ozone concentrations ( $\mathrm{Z}$ ). Interactions of $\mathrm{H}$ and $\mathrm{M}$, and $\mathrm{H}, \mathrm{M}$ and $\mathrm{Z}$ also significantly influenced ethylene production of cut orchid (Table 1). Effect of 1-MCP on ethylene production was dependent on orchid hybrids (Figure 1). The DDG produced significantly higher ethylene with or without exposure to 1-MCP compared to MCJ. However, in the control, MCJ produced much less ethylene than DDG. This showed that 1-MCP was not effective in controlling the endogenous ethylene production of DDG, a hybrid which is naturally a high producer of ethylene. However, 1-MCP managed to significantly reduce the ethylene production of MCJ. This may be because of diversity in time needed for regeneration of ethylene receptors

Table 1. Effects of orchid hybrids (Dendrobium "Darren Glory" (DDG) and Mokara "Calypso Jumbo" (MCJ)), 1- methyl cyclopropane (1-MCP) concentrations, aqueous ozone concentrations and their interactions on ethylene production, vase life, bud opening, ACC content and ACC oxidase activity

\begin{tabular}{|c|c|c|c|c|c|}
\hline Factors & 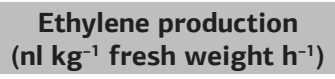 & $\begin{array}{l}\text { Vase Life } \\
\text { (days) }\end{array}$ & $\begin{array}{l}\text { Bud opening } \\
\text { (\%) }\end{array}$ & $\begin{array}{l}\text { ACC content } \\
\left(\mathrm{nmol} \mathrm{g}^{-1}\right)\end{array}$ & $\begin{array}{l}\text { ACC oxidase } \\
\text { activity (\%) }\end{array}$ \\
\hline \multicolumn{6}{|c|}{ Orchid hybrid (H) } \\
\hline DDG & $68.06 \mathrm{a}$ & $10.7 \mathrm{~b}$ & $48.19 \mathrm{a}$ & $7.57 \mathrm{a}$ & $37.86 \mathrm{a}$ \\
\hline MCJ & $3.77 \mathrm{~b}$ & $16.3 \mathrm{a}$ & $41.02 \mathrm{a}$ & $4.05 b$ & $20.25 b$ \\
\hline \multicolumn{6}{|c|}{$\begin{array}{l}\text { 1-MCP concentrations (M) } \\
\left(n L L^{-1}\right)\end{array}$} \\
\hline 0 & $43.75 \mathrm{a}$ & $15.1 \mathrm{a}$ & $33.14 b$ & $7.17 \mathrm{a}$ & $35.85 \mathrm{a}$ \\
\hline 300 & $28.08 b$ & $11.9 \mathrm{~b}$ & $56.07 a$ & $4.45 \mathrm{~b}$ & $22.26 \mathrm{~b}$ \\
\hline \multicolumn{6}{|c|}{$\begin{array}{l}\text { Aqueous ozone concentrations } \\
\text { (Z) }\left(\mathrm{mg} \mathrm{L}^{-1}\right)\end{array}$} \\
\hline 0 & 36.68 a & $12.7 \mathrm{a}$ & $35.72 \mathrm{~b}$ & $5.91 \mathrm{a}$ & $29.56 \mathrm{a}$ \\
\hline 5.2 & $35.15 \mathrm{a}$ & $14.3 \mathrm{a}$ & $53.49 \mathrm{a}$ & $5.71 \mathrm{a}$ & $28.55 \mathrm{a}$ \\
\hline \multicolumn{6}{|l|}{ Interactions } \\
\hline $\mathrm{H} \times \mathrm{M}$ & $* *$ & ns & ns & ns & ns \\
\hline $\mathrm{H} \times \mathrm{Z}$ & ns & $* *$ & ns & ns & ns \\
\hline$M \times Z$ & ns & ns & $*$ & ns & ns \\
\hline $\mathrm{H} \times \mathrm{M} \times \mathrm{Z}$ & $* *$ & $*$ & ns & ns & ns \\
\hline
\end{tabular}

Means, within column and factor, followed by the same letter are not significantly different by Duncan's Multiple Range Test $\left(\right.$ DMRT) at $p \leq 0.05$. $^{\text {ns }},{ }^{*},{ }^{* *}=$ Non-significant and highly significant $\mathrm{p} \leq 0.05$ and $\mathrm{p} \leq 0.01$, respectively. 
or numbers of ethylene receptors. Hence, if some cut orchid hybrids regenerates ethylene receptors in short period of times, 1-MCP should be applied frequently for blocking their newly produced receptors. If the number of ethylene receptors is high, they also need higher concentration of 1-MCP (Dal Cin et al., 2006). This result closely resembles to the findings of Abdi et al. (1998) who reported that $1-\mathrm{MCP}$ affected ethylene production differently in various palm cultivars. However, endogenous ethylene production is not the single determining factor of ethylene sensitivity because MCJ produced small amount of ethylene but is very sensitive to exogenous ethylene. Porat et al. (1994) reported that the acceleration in ethylene sensitivity of Dendrobium flowers following the high production of ethylene caused by pollination was not dependent on endogenous ethylene level. The DDG produced much more ethylene compared to MCJ (Table 1). Flowers of various taxa (Woltering \& Van Doorn, 1988) and even different cultivars of same species (Mayak \& Tirosh, 1993; Wu et al., 1991) produced different rates of ethylene. So, it could be suggested that the behaviour of the orchid hybrids toward treatments also depended on their genetic capabilities. The DDG produced highest and similar rate of ethylene irrespective of 1-MCP

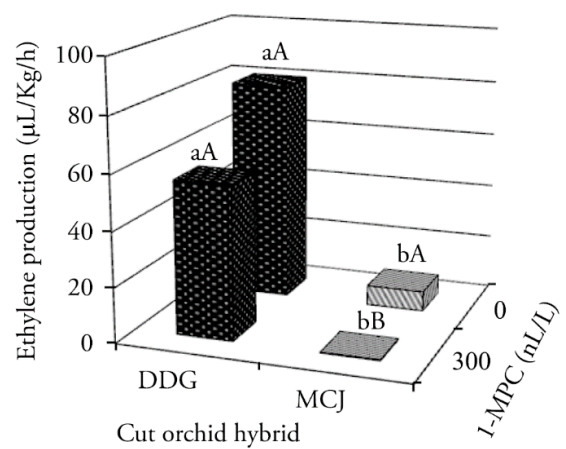

Figure 1. Effect of hybrid (DDG and MCJ) and 1-MCP concentrations on ethylene production. Small letters show the mean comparisons between hybrids within same 1-MCP concentration and capital letters show comparison between 1-MCP concentrations within the same hybrid by DMRT at $\mathrm{p} \leq 0.05$. and ozone concentrations, while MCJ produced highest rate of ethylene only when 1-MCP was not applied (Table 2). In our study, application of 1-MCP resulted in much lower ethylene production by cut orchid. A similar outcome was reported by Uthaichay et al. (2007) on Dendrobium 'Karen', as they found that application of $500 \mathrm{~nL} \mathrm{~L}^{-1} 1$-MCP in cardboard boxes, reduced ethylene production compared to that of control (without 1-MCP). Also, Yamane et al. (2004) reported that 1-MCP treatment effectively suppressed ethylene production of Cattleya alliances and extended their vase lives significantly.

\section{Bud opening}

As shown in table 1, bud opening in cut orchid was significantly influenced by $1-\mathrm{MCP}$ concentrations $(\mathrm{M})$ and aqueous ozone concentrations (Z), but not by orchid hybrid $(\mathrm{H})$. Interactions of $\mathrm{M}$ and $\mathrm{Z}$ also significantly influenced bud opening in cut orchid. 1-MCP treatment significantly improved bud opening by about $70 \%$. This positive effect could be due to the suppression effect of 1-MCP on ethylene action and production, and also reduction in ethylene sensitivity of buds (Sun et al., 2009). Application of aqueous ozone resulted in improvement of bud opening by about $50 \%$. This could probably be related to its inhibition effect on microbial growth in the vase solution and consequently improvement of water conductivity in the xylem (Robinson et al., 2009). The interaction effects between aqueous ozone and 1-MCP pretreatment on the bud opening has been shown in figure 2. Pretreatment of inflorescence with $300 \mathrm{~nL} \mathrm{~L}^{-1} 1-\mathrm{MCP}$ showed that there was no significant difference in the bud opening between using $5.2 \mathrm{mg} \mathrm{L}^{-1}$ aqueous ozone and control. However, when the flowers were not pretreated with 1-MCP, the addition of aqueous ozone into the vase solution increased bud opening. So, without 1-MCP treatment, aqueous ozone significantly increased \% bud opening, but with 1-MCP application, no effect of ozone was observed. This confirms that ozone treatment is effective in absence of 1-MCP.

Table 2. Interactions between hybrid [Dendrobium 'Darren Glory' (DDG) and Mokara 'Calypso Jumbo' (MCJ)], 1-MCP (0 and 300 nL L'-1) and aqueous ozone ( 0 and $5.2 \mathrm{mg} \mathrm{L}^{-1}$ ) on ethylene production and vase life

\begin{tabular}{|c|c|c|c|c|}
\hline \multicolumn{3}{|c|}{ Factors } & \multirow{2}{*}{$\begin{array}{l}\text { Ethylene production } \\
\qquad\left(\mathrm{nl} \mathrm{kg} \mathrm{h}^{-1}\right)\end{array}$} & \multirow{2}{*}{$\begin{array}{l}\text { Vase life } \\
\text { (day) }\end{array}$} \\
\hline Hybrid & 1-MCP (nL L-1) & Ozone (mg L'-1) & & \\
\hline \multirow{4}{*}{ DDG } & 0 & 0 & $88.52 \mathrm{a}$ & $7.80 \mathrm{bc}$ \\
\hline & & 5.2 & $71.93 a$ & $11.40 \mathrm{~b}$ \\
\hline & 300 & 0 & $62.19 \mathrm{a}$ & $9.11 \mathrm{~b}$ \\
\hline & & 5.2 & $49.59 \mathrm{a}$ & $14.40 \mathrm{a}$ \\
\hline \multirow{4}{*}{ MCJ } & 0 & 0 & $8.62 \mathrm{a}$ & $13.00 \mathrm{~b}$ \\
\hline & & 5.2 & $5.94 a$ & $15.40 \mathrm{~b}$ \\
\hline & 300 & 0 & $0.52 \mathrm{~b}$ & $20.80 \mathrm{a}$ \\
\hline & & 5.2 & $0.00 \mathrm{~b}$ & $16.00 \mathrm{~b}$ \\
\hline
\end{tabular}

Means, within column and factor, followed by the same letter are not significantly different by Duncan's Multiple Range Test (DMRT) at $\mathrm{p} \leq 0.05$. 


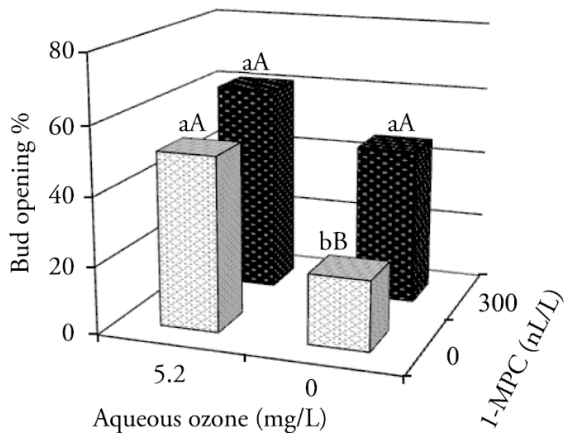

Figure 2. Relationships between aqueous ozone and 1-MCP concentrations on percentage of bud opening. Small letters show the mean comparisons between aqueous ozone treatments and capital letters show the mean comparison within 1-MCP pretreatments, by DMRT at $\mathrm{p} \leq 0.05$.

\section{Vase life}

Orchid hybrid $(\mathrm{H})$ and 1-MCP concentrations (M) exerted significant influence on vase life of cut orchids, but vase life was found independent of ozone concentrations (Z); only $\mathrm{H}$ and $\mathrm{Z}$, and $\mathrm{H}, \mathrm{M}$ and $\mathrm{Z}$ interacted significantly to influence vase life of cut hybrid (Table 1). Vase life of MCJ was about 6 days longer than DDG. Normally, hybrids with higher ethylene production (DDG) have shorter vase life than hybrids with lower ethylene production (MCJ) and vice versa. This observation is in conformity with the results of Wu et al. (1991) and Onozaki et al. (2001) on carnation, which reported that various cultivars displayed different vase lives and those cultivars with low ethylene production, had a longer vase life. Pretreatment with 1-MCP also prolonged vase life of the cut orchid flowers by about three days compared with control (Table 1). Significant interaction between hybrid and aqueous ozone on the vase life of cut orchid hybrids has been presented in figure 3 . The vase life of DDG orchid hybrid was significantly improved with addition of aqueous ozone $\left(5.2 \mathrm{mg} \mathrm{L}^{-1}\right)$ in the vase solution, but vas life of MCJ hybrid remained unchanged despite ozone pretreatment. This might be rooted in the fact that for DDG, in addition to its ethylene sensitivity, xylem blockage might have a role in its vase life because with ozone application, the vase life of DDG was about 4 days longer than control. This finding is consistent with those of Robinson et al. (2009) on cut rose, whereby, the ozone significantly extended its vase life due to the inhibition of xylem blockage. Another interesting significant interaction was observed between hybrid×1-MCP×ozone (Table 2). It was observed that vase life of each hybrid was differently affected by 1-MCP and ozone treatments. The maximum vase life for DDG was recorded when 1-MCP $\left(300 \mathrm{~nL} \mathrm{~L}^{-1}\right)$ in concomitant with aqueous ozone $\left(5.2 \mathrm{mg} \mathrm{L}^{-1}\right)$ were applied, but for MCJ, maximum vase life was observed when

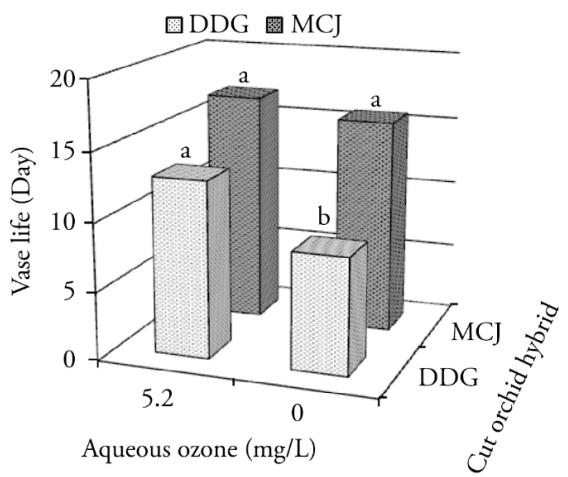

Figure 3. Interaction effect of orchid hybrids, and aqueous ozone concentrations on the vase life. Small letters shows the mean comparisons between ozone treatments in each hybrid and capital letters show the comparison within two hybrids for each ozone treatment by DMRT at $\mathrm{p} \leq 0.05$.

orchid hybrid was pretreated with only 1-MCP $\left(300 \mathrm{~nL} \mathrm{~L}^{-1}\right)$ without aqueous ozone treatment (Table 2).

\section{ACC content and ACC oxidase activity}

The ACC content and ACC oxidase activity of cut hybrid were significantly influenced by hybrid and 1-MCP concentration, but not by aqueous ozone concentration. There were no significant interactions among the factors (Table 1). DDG contained significantly higher ACC compared to MCJ. The difference was almost double. This could probably be one of the reasons why MCJ had a longer vase life compared than DDG. Our findings are not consistent with those of Ketsa \& Luangsuwalai (1996), who reported that there were no significant differences in ACC content of pollinia among six different Dendrobium cultivars. This may be due to the fact that, in the current study comparisons were made between two different genera (Dendrobium and Mokara) and samples were taken from whole floret. In their study the comparisons were made amongn different cultivars from same genus, and also samples were extracted from the pollinia not from the whole florets. It was evident from our study that pretreatment with1-MCP at the rate of $300 \mathrm{~nL} \mathrm{~L}^{-1}$ reduced the ACC content of cut orchids by around $38 \%$ as compared with control (Table 1). Like ACC content, ACC oxidase activity of cut orchid was also recorded higher (86\%) with DDG as compared with MCJ, and 1-MCP treatment reduced ACC oxidase activity by $38 \%$ when compared with without 1-MCP fumigation control. The 1-MCP is known to block the reaction site of ethylene resulting in accumulation of endogenous ethylene. This could halt the rate of further ethylene synthesis and thus, resulted in a lower ACC content, a substrate for ethylene synthesis. These results are in agreement with the observations of Uthaichay et al. (2007) on Dendrobium orchids which reported that $500 \mathrm{~nL} \mathrm{~L}^{-1}$ 1-MCP significantly decreased ACC synthase activity and consequently ACC content. 


\section{Scanning electron microscopy}

The SEM was carried out to observe the effect of aqueous ozone treatment on probable blockages in xylem. The results confirmed the efficacy of aqueous ozone as an anti-microbial agent in reducing vascular blockage (Figures 4 to 7). Figures 4 and 5 were respectively the longitudinal and cross sections of the base of DDG stem. It could be observed that accumulation of microorganisms in xylem vessels leading to partial stem occlusion in flower stem kept in vase solution containing distilled water on day five (parts (a) in Figures 4, 5). Also, there were a host of bacterial colonies within the xylem vessels. However, the aqueous ozone treatment decreased the number of bacteria and diminished the occlusion of xylem vessels (parts (b) in Figures 4, 5). Figures 6 and 7 were respectively the longitudinal and cross sections of the base of MCJ stem. The SEM showed a positive influence of aqueous ozone pre-treatment on the reduction of stem occlusion of DDG as compared with control (no aqueous ozone pre-treatment). Similar results were reported by Robinson et al. (2009) on rose cut flowers. These results revealed that partial xylem blockage observed in the studied cut orchid after harvest and bacterial accumulation on the cut surface of the flower stem did not significantly obstruct water uptake. Thus, their vase lives were not significantly changed despite reduction in the number of microbes and microbial blockage. These findings prove that major reason for shortening of vase lives in these cut orchids is not microbial blockages in xylem but is ethylene sensitivity.
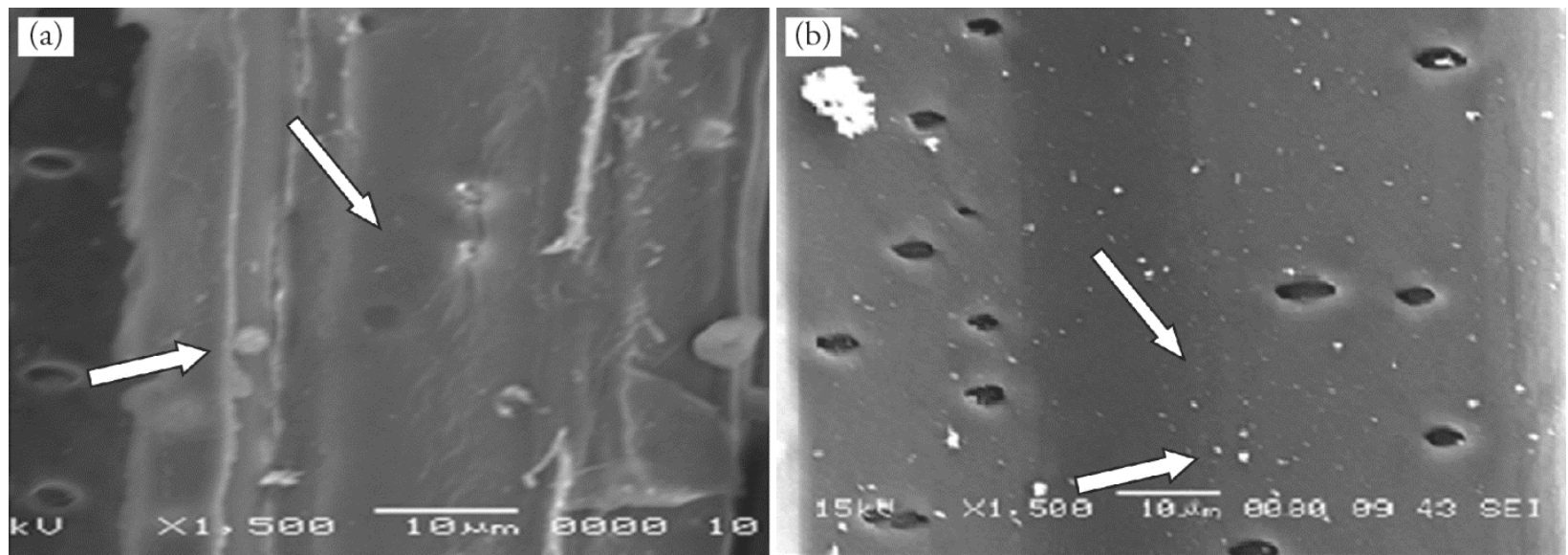

Figure 4. Longitudinal section of the stem base of Dendrobium "Darren Glory" cut orchid in vase solution containing (a) Distilled water (control), showing the microbial colonies and blockages in xylem (arrows in section (a)) and (b) $5.2 \mathrm{mg} \mathrm{L}^{-1}$ aqueous ozone with daily changing of the vase solution. The section was taken after 5 days in vase solution. The accumulation of bacteria in xylem vessels and cell walls of control flowers lead to partial plugging and blockage in the xylem (arrows in section (a)). There are bacterial colonies within border pits of xylem.
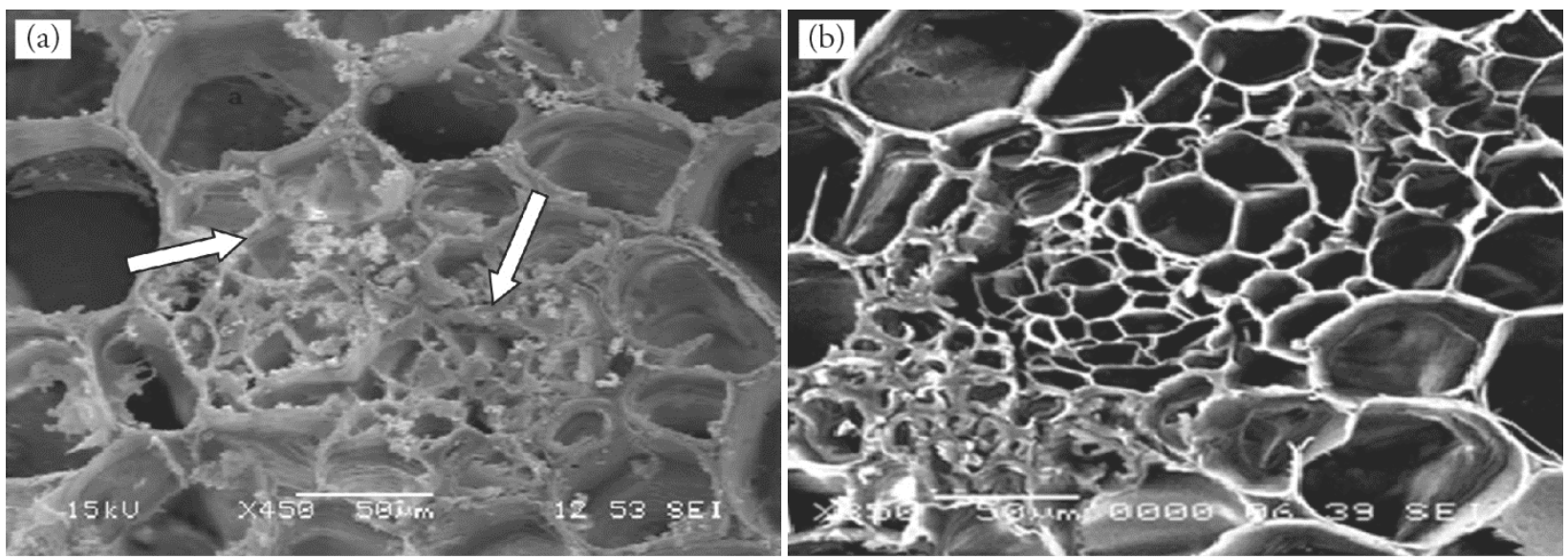

Figure 5. Cross section of the base of Dendrobium "Darren Glory" (DDG) cut orchid flower stem i (a) Distilled water (control) and (b) Aqueous ozone (5.2 $\mathrm{mg} \mathrm{L}^{-1}$ ) as vase water changed daily shows less microbial colony compare to control. The section was taken after five days in vase solution. The accumulation of microorganisms in xylem vessels and their cell wall of untreated flowers lead to partially plugging. Arrows in section (a) show microbial colonies within xylem. 


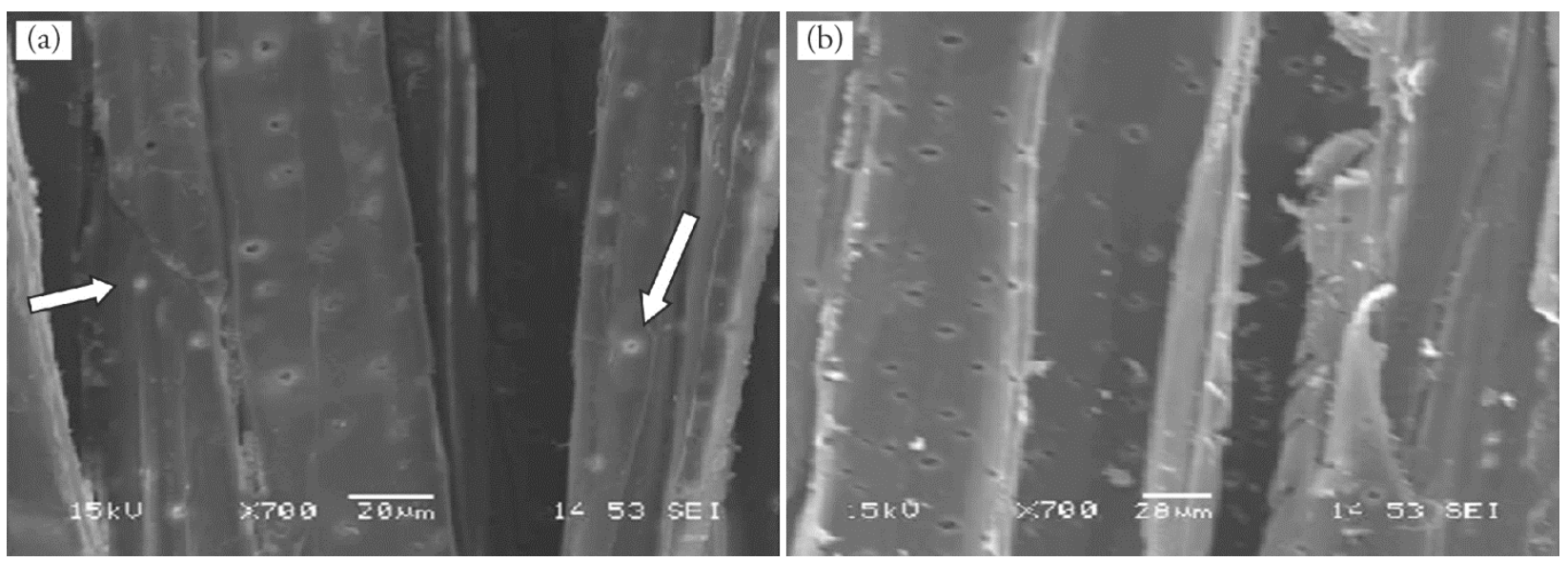

Figure 6. Longitudinal section of the base of Mokara "Calypso Jambo" (MCJ) cut flower stem. (a) Distilled water without changing holding solution, arrows in section (a) shows many of border pits are blocked compare to the control (b) Aqueous ozone $\left(5.2 \mathrm{mg} \mathrm{L}^{-1}\right)$ as vase water daily changing. The section was taken on day five in vase solution. The accumulation of microorganisms in xylem vessels and their cell wall of untreated flowers lead to partially plugging (arrows in section (a)).
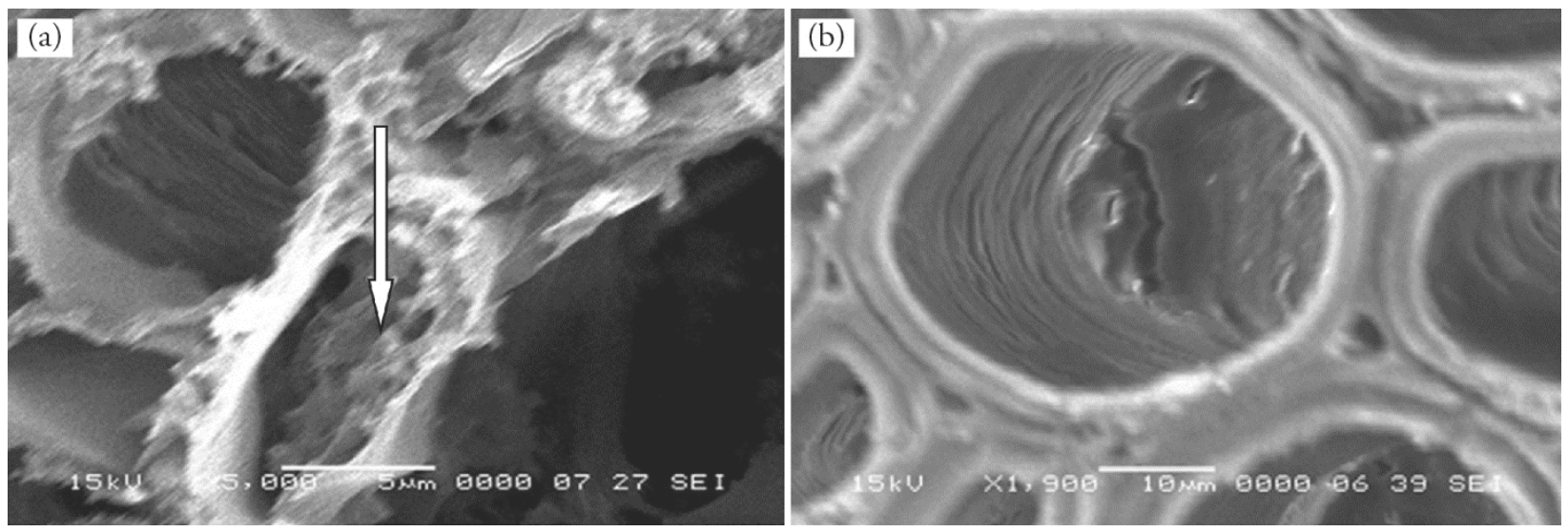

Figure 7. Cross section of the base of Mokara "Calypso Jambo" (MCJ) cut flower stem. (a) Distilled water without changing holding solution and (b) Aqueous ozone $\left(5.2 \mathrm{mg} \mathrm{L}^{-1}\right)$ as vase water daily changing. The section was taken on day five in vase solution. The accumulation of microorganisms in xylem vessels and their cell wall of untreated flowers lead to partially plugging. There are bacterial colonies and their bodies within xylem (Arrow in section (a)).

\section{CONCLUSION}

Pretreatment of the cut orchid flowers with $300 \mathrm{~nL} \mathrm{~L}^{-1}$ 1-MCP, followed by using $5.2 \mathrm{mg} \mathrm{L}^{-1}$ aqueous ozone as the vase solution could be recommended as postharvest treatments to maintain quality and extend vase life of both the DDG and MCJ orchid hybrids. In addition, 1-MCP pretreatment for MCJ was very effective in extending vase lives and increasing percentage bud opening. Another important finding of this study was that the main reason behind the short vase life of orchids was ethylene sensitivity of the cut flowers and not the xylem blockage. It was also evident that aqueous ozone markedly contributed to the inhibition of microbial growth in vase solution.

\section{REFERENCES}

Abdi, N., Mcglasson, W. B., Holford, P., Williams, M., \& Mizrah, Y. (1998). Responses of climacteric and suppressed-climacteric plums to treatment with propylene and 1-methylcyclopropene. Postharvest Biology and Technology, 14, 29-39. http://dx.doi.org/10.1016/ S0925-5214(98)00031-3.

Adams, P. B. (2011). Systematics of Dendrobiinae (Orchidaceae), with special reference to Australian taxa. Boany Journal of Linnean Society, 166, 105-126. http://dx.doi.org/10.1111/j.1095-8339.2011.01141.x.

Chen, S., Tsi, Z., Luo, Y., \& Zeng, J. (1999). Native orchids of China in colour. Beijing: Science Press.

Dal Cin, V., Rizzini, F. M., Botton, A., \& Tonutti, P. (2006). The ethylene biosynthetic and signal transduction pathways are 
differently affected by $1-\mathrm{MCP}$ in apple and peach fruit. Postharvest Biology and Technology, 42, 125-133. http://dx.doi.org/10.1016/j. postharvbio.2006.06.008.

Dressler, R. L. (1990). The orchids: natural history and classification. London: Harvard University Press.

Goh, C. J., Halevy, A. H., Engel, R., \& Kofranek, A. M. (1985). Ethylene evolution and sensitivity in cut orchid flowers. Scientia Horticulturae, 26, 57-67. http://dx.doi.org/10.1016/0304-4238(85)90102-5.

Hew, C. S., \& Yong, J. W. H. (2004). The physiology of tropical orchids in relation to the industry (2nd ed.). Singapore: World Scientific Publishing.

Ichimura, K., Shimizu, H., \& Hiraya, T. (2002). Effect of 1-methylecyclop-ropene (1 -MCP) on the vase life of cut carnation, delphinium and sweet pea flowers. Bulletin of National Institute of Floricultural Science, 2, 1-8.

Jędrzejuk, A., \& Sakrzewski, J. (2009). Xylem occlusions in the stems of common lilac during postharvest life. Acta Physiologiae Plantarum, 31, 1147-1153. http://dx.doi.org/10.1007/s11738-009-0333-0.

Kazemi, M., \& Ameri, A. (2012). Response of vase-life of carnation cut flower to salicylic acid, silver nanoparticles, glutamine and essential oil. Asian Journal of Animal Science, 6, 122-130. http://dx.doi. org/10.3923/ajas.2012.122.131.

Ketsa, S., \& Luangsuwalai, K. (1996). The relationship between 1-aminocyclopropane-1-carboxylic acid content in pollinia, ethylene production and senescence of pollinated Dendrobium orchid flowers. Postharvest Biology and Technology, 8, 57-64. http://dx.doi. org/10.1016/0925-5214(95)00053-4.

Kim, J. G., Yousef, A. E., \& Chism, G. W. (1999). Use of ozone to inactivate microorganisms on lettuce. Journal of Food Safety, 19, 7-34. http://dx.doi.org/10.1111/j.1745-4565.1999.tb00231.x.

Kim, J. G., Yousef, A. E., \& Khadre, M. A. (2003). Ozone and its current and future application in the food industry. Advancas in Food Science and Nutrition, 45, 167-218. http://dx.doi.org/10.1016/ S1043-4526(03)45005-5. PMid:12402681.

Komanapalli, I. R., \& Lau, B. H. S. (1998). Inactivation of bacteriophage $\mathrm{k}$, Escherichia coli, and Candida albicans by ozone. Applied Microbiology and Biotechnology, 49, 766-769. http://dx.doi. org/10.1007/s002530051244. PMid:9684309.

Komanapalli, I. R., Mudd, J. B., \& Lau, B. H. S. (1997). Effect of ozone on metabolic activities of Escherichia coli K-12. Toxicology Letters, 90, 61-66. http://dx.doi.org/10.1016/S0378-4274(96)038301. PMid:9020403.

Lizada, C., \& Yang, S. F. (1979). A simple and sensitive assay for 1-aminocyclopropane-1-carboxylic acid. Analytical Biochemistry, 100, 140-145. http://dx.doi.org/10.1016/0003-2697(79)90123-4. PMid:543532.

Mayak, S., \& Tirosh, T. (1993). Unusual ethylene-related behavior in senescing flowers of the carnation sandrosa. Physiologia Plantarum, 88, 420-426. http://dx.doi.org/10.1111/j.1399-3054.1993.tb01354.x.

Onozaki, T., Ikeda, H., \& Yamaguchi, T. (2001). Genetic improvement of vase life of carnation flowers by crossing and selection. Scientia
Horticulturae, 87, 107-120. http://dx.doi.org/10.1016/S03044238(00)00167-9.

Oyedotun, K. S., \& Lemire, B. D. (2004). The quaternary structure of the Saccharomyces cerevisiae succinate dehydrogenase: homology modeling, cofactor docking, and molecular dynamics simulation studies. The Journal of Biological Chemistry, 279, 9424-9431. http:// dx.doi.org/10.1074/jbc.M311876200. PMid:14672929.

Podd, L. A., Hills, P. N., \& Van Staden, J. (2002). Physiological response and extension of vase life of cut carnation flowers treated with ethanol and acetaldehyde. II. Protein content and enzyme activity. Plant Growth Regulation, 38, 107-117. http://dx.doi. org/10.1023/A:1021219829005.

Porat, R., Borochov, A., \& Halevy, A. H. (1994). Pollination-induced changes in ethylene production and sensitivity to ethylene in cut Dendrobium orchid flowers. Scientia Horticulturae, 58, 215-221. http://dx.doi.org/10.1016/0304-4238(94)90153-8.

Robinson, S., Graham, T., Dixon, M. A., \& Zheng, Y. (2009). Aqueous ozone can extend vase-life in cut rose. The Journal of Horticultural Science \& Biotechnology, 84, 97-101.

Singh, A. K. (2006). Orchids: cultivation and management. Pitam Pura: New India Publishing.

Singh, R., \& Jaroenkit, T. (2011). Effects of 1-MCP and storage temperature on vase life of cut Mokara inflorescences. Agrcultural Science Journal, 42, 351-354.

Staehelin, J., Buehler, R. E., \& Hoigne, J. (1984). Ozone decomposition in water studied by pulse radiolysis. 2. $\mathrm{OH}$ and $\mathrm{HO} 4$ as chain intermediates. Journal of Physical Chemistry, 88, 5999-6004. http:// dx.doi.org/10.1021/j150668a051.

Sun, Y., Christensen, B., Liu, F., Wang, H., \& Müller, R. (2009). Effects of ethylene and 1-MCP (1-methylcyclopropene) on bud and flower drop in mini Phalaenopsis cultivars. Plant Growth Regulation, 59, 83-91. http://dx.doi.org/10.1007/s10725-009-9391-y.

Torre, S., \& Fjeld, T. (2001). Water loss and postharvest characteristics of cut roses grown at high or moderate relative air humidity. Scientia Horticulturae, 89, 17-26. http://dx.doi.org/10.1016/S03044238(00)00229-6.

Twumasi, P., Van Ieperen, W., Woltering, E. J., Emons, A. M. C., Schel, J. H. N., Snel, J. F. H., Van Meeteren, U., \& Van Marwijk, D. (2005). Effects of water stress during growth on xylem anatomy, xylem functioning and vase life in three Zinnia elegans cultivars. Acta Horticulturae, 669, 303-311.

Uthaichay, N., Ketsa, S., \& Van Doorn, W. G. (2007). 1-MCP pretreatment prevents bud and flower abscission in Dendrobium orchids. Postharvest Biology and Technology, 43, 374-380. http:// dx.doi.org/10.1016/j.postharvbio.2006.09.015.

Van Doorn, W. G. (1998). Effects of daffodil flowers on the water relations and vase life of roses and tulips. Journal of the American Society for Horticultural Science, 123, 146-149.

White, J. (1996). Taylor's guide to orchids: more than 300 orchids, photographed and described, for beginning to expert gardeners. New York: Houghton Mifflin Press. 
Woltering, E. J., \& Van Doorn, W. G. (1988). Role of ethylene in senescence of petals - morphological and taxonomical relationships. Experimental Botany, 39, 1605-1616. http://dx.doi.org/10.1093/ jxb/39.11.1605.

Wu, M. J., Van Doorn, W. G., \& Reid, M. S. (1991). Variation in the senescence of carnation (Dianthus caryophyllus L.) cultivars. I. Comparison of flower life, respiration. Scientia
Horticulturae, 48, 99-107. http://dx.doi.org/10.1016/03044238(91)90156-S.

Yamane, K., Yamaki, Y., \& Fujishige, N. (2004). Effects of exogenous ethylene and 1-MCP on ACC oxidase activity, ethylene production and vase life in cattleya alliances. Journal of the Japanese Society for Horticultural Science, 73, 128-133. http://dx.doi.org/10.2503/ jjshs.73.128. 